\title{
The Enforcement of Business Competition Law by the Police: An Indonesian Experience
}

\author{
Hari Sutra Disemadi \\ Diponegoro University, Indonesia \\ haridisemadi@gmail.com
}

Kholis Roisah

Diponegoro University, Indonesia

r_kholis@yahoo.com

\begin{abstract}
In Indonesia, the Commission for the Supervision of Business Competition or Komisi Pengawas Persaingan Usaha (KPPU) is granted the power according to Law Number 5 of 1999 but such a power cannot be optimally implemented. KPPU often experiences difficulties and obstacles in the process of enforcing business competition law due to a large number of business actors and uncooperative witnesses so that this hinders the process of examining cases. In particular, KPPU has lack of cooperation of involved parties during the inspection process. However, the KPPU in carrying out its authority can include the role of the Indonesian police to assist in the process of enforcing business competition law. This paper shows that the role of the Indonesian police in the enforcement of business competition law can be initiated during the investigation process if the KPPU requests assistance to present the reported party, witnesses, and expert witnesses. Until the decision is issued by the KPPU, investigators can follow up with relevant individuals that may have cases that contain criminal aspects.
\end{abstract}

KEYWORDS: Business Competition Law, Commission for the Supervision of Business Competition, Indonesian Police.

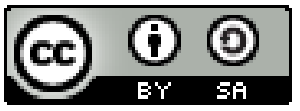

Copyright $\odot 2019$ by Author(s)

This work is licensed under a Creative Commons Attribution-ShareAlike 4.0 International License. All writings published in this journal are personal views of the authors and do not represent the views of this journal and the author's affiliated institutions.

\section{HOW TO CITE:}

Disemadi, Hari Sutra \& Kholis Roisah. "The Enforcement of Business Competition Law by the Police: An Indonesian Experience” (2019) 6:2 Lentera Hukum 203-214.

Submitted: July 14, 2019 Revised: July 23, 2019 Accepted: July 25, 2019 


\section{INTRODUCTION}

It has been 20 years since Law Number 5 of 1999 on Prohibition of Monopolistic Practices and Unfair Business Competition was promulgated in 1999. This law grants authority to the Business Competition Supervisory Commission or KPPU, but has not been implemented optimally. ${ }^{1}$ KPPU often experiences difficulties and obstacles in the law enforcement process. This is due to the large number of business actors, as well as the amount of uncooperative witnesses, thus hampering the process of examining cases. Another obstacle faced by KPPU is that the reported party does not want to submit documents or evidence requested in the inspection process. In dealing with a cartel case, for example, it requires complete facts and evidence so that the decision can provide legal certainty. However, in obtaining data and evidence it is not uncommon for business actors (reported) to refuse to provide documents and data needed in the inspection process. ${ }^{2}$ This condition will greatly affect the quality of KPPU decisions. Further, the KPPU does not have the authority to confiscate, search, or seize documents that can be used as evidence in the inspection process.

Article 36 letter e of Law Number 5 of 1999 states that the authority of the commission calls on business actors suspected of having violated the provisions of this law" and Article 36 letter $\mathrm{f}$ "the Commission has the authority to call and present witnesses, expert witnesses, and everyone who is considered aware of violations of the provisions of this law. In practice, the KPPU experiences several obstacles as described above. To assist in implementing the authority as mandated in Article 36 letters e and f, the KPPU may request the assistance of investigators. This matter as stipulated in Article 36 letter $\mathrm{g}$ states "the authority of the commission requests the assistance of investigators to present business actors, witnesses, witnesses, or every person as referred to in letter e and letter $\mathrm{f}$, who are not willing to fulfill the Commission's summons". But in Indonesia, the provision does not automatically run as written in the law. The the Police of the Republic of Indonesia Indonesian (POLRI) cannot carry out its duties without cooperation with the KPPU in the form of MoU. ${ }^{3}$

This paper will specifically examine the authority granted to the KPPU and its practice in which the KPPU cannot only appear alone to carry out enforcement of business competition law. ${ }^{4}$ In particular, the role of POLRI is quite important in assisting KPPU in the process of enforcing business competition law. It does not rule out the possibility of business competition cases containing criminal charges. For business ac-

1 Supriatna. (2016). Persekongkolan Bisnis Dalam Bentuk Perjanjian Kartel. Jurnal Hukum POSITUM. Vol.1 (No.1), pp. 124-140 at 131.

2 Mantili, R., Kusmayanti, H., \& Afriana, A. (2016). The Problem of Law Enforcement in Business Competition in Estabilishing Legal Certainty. PADJADJARAN Jurnal Ilmu Hukum, Vol.3 (No.l), pp. 116132, DOI: https://doi.org/10.22304/pjih.v3nl.a7 at 118.

3 Komisi Pengawas Persaingan Usaha (KPPU), KPPU-POLRI: Pererat Kerjasama Dengan Pengesahan Prosedur Pelaksanaan MOU, Available online from: http://www.kppu.go.id/id/blog/2011/05/kppupolri-pererat-kerjasama-dengan-pengesahan-prosedur-pelaksanaan-mou/ Accessed in July 1, 2019.

4 Fadhilah, M. (2019). Penegakan Hukum Persaingan Usaha Tidak Sehat Oleh Komisi Pengawas Persaingan Usaha (KPPU) Dalam Kerangka Ekstrateritorial. Jurnal Wawasan Yuridika, Vol.3 (No.l), pp.55-72, DOI: http://dx.doi.org/10.25072/jwy.v3il.217 at 62. 
tors who refuse to be examined, refusing to provide information needed in investigations and/or examinations, or blocking the inspection process can be submitted to the investigator. In this case an investigation can be carried out in accordance with the authority of the applicable provisions.

The purpose of this study is a reflection of the problems that arise in the writing above, so the objectives to be achieved are: first, to understand the role of the Indonesian National Police in enforcement of business competition law in Indonesia and secondly, to find out how the KPPU and POLRI relate to handling business competition cases.

\section{THE ROLE OF THE POLICE OF THE INDONESIAN POLICE IN BUSINESS COMPETITION LAW}

Supervising the implementation of Law Number 5 of 1999 requires the establishment of a commission. This formation is based on Article 34 of Law Number 5 of 1999 which instructs that the formation of the organizational structure, duties and functions of the commission be determined through a Presidential Decree. This commission was then formed based on Presidential Decree Number 75 of 1999 and named the Business Competition Supervisory Commission or KPPU. ${ }^{5}$

Thus it is clear that the, enforcement of business competition law is within the authority of the KPPU. However, it does not mean that no other institution has the authority to handle cases of monopoly practices and unfair business competition. ${ }^{6}$ The District Court (PN) and the Supreme Court (MA) were also authorized to complete the case. The Distict Court is given the authority to handle objections to KPPU decisions and handle violations of competition law which are criminal cases because the KPPU ruling has not been implemented. To enter the process of the trial, of course, the role of the Indonesian National Police in assisting the business competition law enforcement process is very necessary as stated in various articles in Law Number 5 of 1999 which will be described below. In this circumstance, the Supreme Court is given the authority to settle cases of violation of competition law exclusively if there was an appeal against the decision of the District Court.

As an institution formed independently based on Law Number 5 of 1999, KPPU has the authority to investigate, examine and decide cases, and adjudicate allegations of monopolistic practices and unfair business competition. ${ }^{7}$ With the authority of the KPPU to examine and decide on alleged monopolies and unfair business competition, the KPPU is a commission that runs and includes executive functions and judicial func-

5 Simbolon, A.P. (2008). Komisi Pengawas Persaingan Usaha Dalam Penegakan Hukum Persaingan Usaha. Jurnal Mimbar Hukum, Vol.20 (No.3), pp.459-471, DOI: https://doi.org/10.22146/jmh.16288 at 463.

6 Fadhilah, M, supra note 4 at 69.

7 Silalahi, U. (2018). Single Economic Entity: Kajian Hukum Persaingan Usaha Di Indonesia, Jurisdictie: Jurnal Hukum dan Syariah, Vol.9 (No.1), pp.1-24, DOI: http://dx.doi.org/10.18860/j.v9il.4903 at 15. 
tions that still refer to and are based on the applicable legal system in the Republic of Indonesia.

In the context of constitutionality, KPPU is a complementary state institution (state auxiliary organ) which has authority based on Law Number 5 of 1999 to enforce business competition law. In simple terms, the state auxiliary organ is a state institution formed outside the constitution and is an institution that assists the implementation of the tasks of the principal state institutions (Executive, Legislative and Judicative) which are often also referred to as pseudo independent institutions of the state (quasi). ${ }^{8}$ The role of a pseudo independent institution becomes important as a responsive effort for countries that are in the middle of the transition from authoritarianism to democracy. ${ }^{9}$

In carrying out its duties and authorities, KPPU can take several actions in accordance with Law Number 5 of 1999, such as receiving reports from the public or from business actors related to alleged monopolies and unfair business competition, conducting research on these reports, carrying out inspections both preliminary and advanced, calling on business actors, witnesses and experts and request information from relevant agencies to make decisions, and imposing administrative sanctions on business actors who are considered to violate Law Number 5 Year 1999.

One of the KPPU responsibilities is to dig up information related to the report being examined.The parties include business actors both reported and reporters, witnesses,and expert statements as well as the results of documents submitted at the time of registration of the case. In the process of summoning business actors, witnesses and experts to be questioned on examination, KPPU experiences the mostdifficulties and obstacles. This is due to the large number of business actors, as well as witnesses who are less than cooperative, thus hampering the process of examining cases.

KPPU Investigators often experience difficulties in presenting the parties referred to in the article above both at the time of the preliminary examination and at the time of further investigation. This condition will certainly affect the performance and quality of KPPU decisions. And it should be noted that the KPPU may not decide in absentia in other words all parties to the litigation must be able to be presented during the examination process. ${ }^{10}$

The role of POLRI in the process of enforcing competition law come into play when business actors refuse to be examined, refuse to provide information needed in investigations and / or examinations, or hinder the process of investigation and / or examination, this provision is mentioned in Article 41 paragraph (2) of Law Number 5 in 1999. The provisions of Article 261 of the Criminal Code state that the refusal of the in-

8 Chandra, A., and Widiyaatuti, Y.S.M. (2017). Peran Komisi Pengawas Persaingan Usaha (KPPU) Dalam Mendorong Iklim Persaingan Usaha Yang Sehat Di Sektor Perunggasan. Jurnal Justisi et Pax, Vol.33 (No.1), pp.1-ll, DOI: https://doi.org/10.24002/jep.v33il.1416 at 2.

9 Komisi Pengawas Persaingan Usaha (KPPU), Hukum Persaingan Usaha Antara Teks \& Konteks at 312, available at http://www.kppu.go.id/id/media-danpublikasi/buku/ Accessed in June 20, 2019.

10 Mulyadi, D., \& Rusydi, I. (2017). Efektifitas Peran Komisi Pengawas Persaingan Usaha (KPPU) Dalam Penanganan Kasus Persaingan Usaha Tidak Sehat, Jurnal Ilmiah Galuh Justisi, Vol.5 (No.1), pp.120, DOI: http://dx.doi.org/10.25157/jigj.v5il.235 at 13. 
vestigation and examination process carried out by the KPPU can be categorized as a criminal offense. If the provision is violated by the business actor,the KPPU submits it to investigators for investigation according to the provisions in force in Article 41 paragraph (3) of Law Number 5 of 1999. Based on the explanation of article 41 paragraph (3) submitted by the commission to the investigator for investigation is not only an act or crime as referred to in Article 41 paragraph (2) of Law Number 5 of 1999, but also includes the subject matter being investigated and examined by the Commission.

The next role is as stipulated in Article 44 paragraph (5) of Law Number 5 of 1999 that "the commission's decision as referred to in Article 43 paragraph (4) is sufficient initial evidence for the investigator to conduct an investigation". This refers to the provisions of Article 43 (4) that the intended decision is a decision that has legal force remaining at the level of the KPPU and no objection or appeal is filed. This refers to the provisions of Article 44 paragraph (4), that the KPPU will submit a violation of the failure of the KPPU's decision to be made by the business actor and not raise an objection with the KPPU decision. The matter which must be followed up by investigators (POLRI) is the KPPU decision.

Article 216 of the Criminal Code states that: 1). Anyone who intentionally does not obey orders or requests made according to the law by an official whose duty is to supervise something or by an official based on his duties is also authorized to investigate or examine a crime; likewise, anyone who intentionally prevents, obstructs or frustrates actions in order to carry out the provisions of the law carried out by one of these officials is threatened with imprisonment for a maximum of 4 months 2 weeks or a maximum fine of 9 thousand rupiah; 2).Equated with the official above, every person who according to the provisions of the Law continues or is temporarily entrusted with the task of running public office; and 3). If at the time of committing a crime 2 years have passed since the existence of such an offense, then the penalty may increase by one third.

Based on the provisions of article 216 of the Criminal Code mentioned above, the POLRI can exercise its authority, if the parties sanctioned by the KPPU are not voluntary or after going through the fiat execution process to the Court does not implement the KPPU decision. This means that the parties reported conduct defiance of the decisions of public officials in this case KPPU.

There are two types of sanctions stipulated in Law Number 5 of 1999 concerning Prohibition of Monopolistic Practices and Unfair Business Competition. Sanctions in the form of administrative and basic and additional criminal sanctions. Administrative sanctions as stipulated in Article 47 can be in the form of: 1). Determination of cancellation of agreement; 2). Orders to businesses to stop vertical integration; 3). Orders to business actors to stop activities that have been proven to lead to monopolistic practices and unfair business competition and especially harm the community; 4). Orders to business actors to stop abuse of dominant positions; 5). Determination of cancellation or merger or consolidation of business entities and takeover of shares; 6). Determination of compensation payments; and 7). The imposition of fines is as low as one billion 
rupiah (IDR 1.000.000.000) and as high as twenty five billion rupiah (IDR 25.000.000.000).

Basic criminal sanctions as stipulated in Article 48 of Act Number 5 of 1999 concerning imposition of fines or confinement as a substitute for fines with certain rupiah amounts as stated in Article 48 and additional criminal sanctions as stipulated in Article 49 by pointing to Article 10 of the Criminal Code: 1). Revocation of business license; 2). Prohibition to business actors proven to have violated Law Number 5 of 1999 to hold the position of directors or commissioners at least 2 (two) years and no more than 5 (five) years; and 3). Termination of certain actions or activities that cause losses to other parties.

Business actors that have been decided by KPPU can make legal remedies against the District Court (PN) at the legal domicile of the business actor who has been reported, with a maximum period of 14 (fourteen) days from the reading of the decision by the KPPU. If the KPPU's verdict is strengthened by the District Court, then the business actor concerned must implement the prescribed decision. But if not satisfied with the decision of the District Court, the business actor can file an appeal to the Supreme Court (MA). Support and assistance from the Indonesian National Police make the case handling process faster and more efficient both in terms of time, cost and effort. This is solely to provide legal certainty and credibility of the institution in front of the community in general and business actors in particular.

\section{RELATIONSHIP OF THE INDONESIAN POLICE AND THE KPPU IN BUSINESS COMPETITION CASES}

KPPU does not have investigators, even though investigators here have a very large role in helping with case handling, meaning that KPPU must first request assistance from the police to assist in handling business competition cases unlike the Financial Services Authority (OJK) which has internal investigators. The internal investigator is a Civil Servant Investigator (PPNS). Civil Servant Investigators (PPNS) are investigators who deal with crime is not usually handled by police investigators. PPNS are certain Civil Servants Officers based on the laws and regulations designated as investigators and have the authority to conduct criminal investigations within the scope of the law which are their respective legal basis.

Each investigation must refer to the provisions of Law Number 8 of 1981 concerning Criminal Procedure Law (KUHAP) and in carrying out its authority, PPNS in any field must coordinate with Police investigators. To regulate the authority of the PPNS, the Indonesian Police Chief Regulation Number 6 of 2010 was issued concerning the Management of Investigation of Civil Servant Investigators. The POLRI's authority as an investigator only exists after a warrant is issued to conduct an investigation. Investigations can be carried out based on the results of an investigation that has sufficient evidence. The authority to investigate is only given to Indonesian National Police Investigators and Civil Servant Investigators, as mandated by Law Number 8 of 1981 in con- 
junction with Law Number 2 of 2002 concerning the National Police of the Republic of Indonesia. The existence of investigators and PPNS needs to be supported to produce effective and efficient performance.

The importance of the presence of investigators in enforcing business competition law as ultimum remedium is felt when administrative problems are no longer able as a way out in solving a business competition case. This is what KPPU is aware of and therefore KPPU has also sought to be able to cooperate with investigators in the context of enforcement of business competition law.

In carrying out its duties related to the cooperation of POLRI with KPPU, the police carry out law enforcement functions in accordance with Article 2 of Law Number 2 of 2002 concerning the Police of the Republic of Indonesia. In carrying out the law enforcement function, the POLRI is involved in cooperation with many other state institutions, including with KPPU in law enforcement of monopoly practices and unfair business competition. POLRI is under the President and is responsible to the President. POLRI led by the Indonesian Police Head (KAPOLRI) who was also appointed, dismissed, and held accountable for his policies to the President.

The main tasks of POLRI as stated in Article 13 of Law Number 2 Year 2002 are: 1). Maintaining security and public order; 2). Enforce the law; and 3). Providing protection, protection and service to the community. It is clearly stated that one of the duties of the police is to enforce the law, including in it is business competition law which is escorted by KPPU. It is explained in more detail in Article 14 of Act No. 2 of 2002 that the police can conduct investigations and investigations on all matters that meet the elements of criminal offenses in accordance with the provisions of the Criminal Code and other laws and regulations. Based on the provisions of the article, the police can carry out investigations and investigations into violations of Law Number 5 of 1999 if ordered. In relation to cooperation carried out with KPPU, the police can assist KPPU investigators with cases of monopolistic practices and unfair business competition that contain elements of criminal acts.

For cases originating from violations of Law Number 5 of 1999 which certainly contain criminal elements, investigators (POLRI) can use a legal basis based on the Criminal Code for their material law and KUHAP for formal law jo. Law Number 5 of 1999. In criminal sanctions as stipulated in the second part of Article 48 of Law Number 5 of 1999, regarding basic crimes and Article 49 concerning additional crimes, it is clearly the authority of the police. Therefore, to provide the aforementioned sanctions, of course, it must start from the process of investigation and investigation by the police and then arrive at the trial process in court.

Article 48 of Law Number 5 of 1999 stipulates that basic criminal sanctions include a fine of at least twenty five billion rupiah (IDR 25.000.000.000) and a maximum of one hundred billion rupiah (IDR 100.000.000.000). Criminal penalties can be replaced with imprisonment for a maximum of 6 months. This criminal sanction is given by the court (not the KPPU authority) if: 1). There was a violation of the provisions of Article 4, 9-14, 16-19, 25, 27 and Article 28 of Law Number 5 of 1999. The perpetrators 
were threatened with a criminal as low as twenty five billion rupiah (IDR 25.000.000.000) and a maximum one hundred billion rupiah (IDR 100.000.000.000) or imprisonment in lieu of a fine for 6 months; 2). There was a violation of the provisions of Articles 5-8, 15, 20-24 and Article 26 of Law Number 5 of 1999. The perpetrators were threatened with a fine of at least five billion rupiah (IDR 5.000.000.000) and a maximum of twenty five billion rupiah (IDR 25.000.000.000) or imprisonment instead of a fine of 5 months; and 3). There was a violation of the provisions of Article $4 \mathrm{l}$ of Law Number 5 of 1999. The criminal threat was as low as one billion rupiah (DIR 1.000.000.000) and a minimum of five billion rupiah (IDR 5.000.000.000) or a penalty for replacing a maximum fine of 3 month.

Therefore, if the business actor is not willing to submit evidence both in investigation and examination and refuses to be examined can be subject to basic criminal sanctions as stipulated in Article 48 paragraph (3) Law Number 5 of 1999.

Article 49 of Law Number 5 of 1999 stipulates that additional penalties that can be imposed on business actors can be: 1). Revocation of business permit; 2). Prohibition of business actors who have been proven to have violated this law to hold the position of directors or commissioners for at least 2 years; or 3). Termination of certain activities or actions that cause losses to other parties.

In the general explanation of Law Number 5 of 1999 it is stated that the Commission is only authorized to impose administrative sanctions, while those authorized to impose criminal sanctions are courts. To be able to impose criminal sanctions, of course, it must begin from the process of investigation and investigation carried out by the police. A case handled by KPPU can then be submitted to the investigator and can therefore be sentenced if in the case of: 1).Business actors do not carry out the Commission's decision in the form of administrative sanctions (Article 44 paragraph (4) of Law Number 5 of 1999); and 2).Business actors refuse to be examined, refuse to provide information needed in investigations and/or examinations or hinder the process of investigation and/or examination (Article 41 paragraph (2) of Law Number 5 of 1999).

In response to the two violations, the Commission assigns two investigators. The Commission decision is sufficient preliminary evidence for the investigator to conduct an investigation (Article 41 paragraph (3) in conjunction with Article 44 paragraph (5) of Law Number 5 of 1999. Therefore, with the signing of a collaboration between KPPU and POLRI will handle cases more effectively and efficiently in the context of enforcement of business competition law.

When viewed from the theory of authority which states authority is a term commonly used in the field of public law. Authority is "formal power", executive or administrative power. ${ }^{11}$ Therefore, it is the power of a certain group of people or power over a certain area of government or government affairs. Therefore, the authority possessed by KPPU and POLRI in the enforcement of the Business Competition Law is the authority

11 Sapitri, B.E. (2015). Kewenangan Komisi Pengawas Persaingan Usaha (KPPU) Dalam Penanganan Perkara Persaingan Usaha (Studi Perbandingan Di Indonesia Dengan Negara-Negara Common Law System), Jurnal IUS Kajian Hukum Dan Keadilan, Vo.3 (No.1), pp.139-159, DOI: http://dx.doi.org/10.12345/ius.v3i7.204 at 149. 
of attribution, in which this authority is related to the recognition of rights to a new authority. This authority is also the authority attached to the position or authority formed together with the position. Therefore, any authority that arises from attribution will give birth to an authentic authority. According to Prajudi Atmosudirjo, ${ }^{12}$ authority is the power to carry out an act of public law. Whereas according to Indroarto, ${ }^{13}$ authority is the ability given by legislation that causes legal consequences.

Associated with the role of the Indonesian National Police in the enforcement of Business Competition Law it appears that between POLRI and KPPU are both given the authority by law in accordance with their duties and authorities based on Law Number 5 Year 1999. POLRI as an investigator is given authority by Law Number 5 Year 1999 to assist KPPU in efforts to enforce Business Competition Law.

Ideally, in order to carry out enforcement of business competition law, a large authority is needed, namely the search and seizure authority, which has been the authority of POLRI investigators, many countries have accommodated the investigator's authority into their business competition to maximize theperformance of competition institutions. ${ }^{14}$

\section{CONCLUSION}

The role of the Police of the Republic of Indonesia (POLRI) in the enforcement of Business Competition Law can be initiated during the investigation and examination process in the event that the Business Competition Supervisory Commission (KPPU) requests assistance to present the reported party, witnesses, expert witnesses and anyone involved in business competition cases, and can be followed up by an investigator if it contains criminal aspects.

POLRI and KPPU are both given the authority by law in accordance with their duties and authorities based on Law Number 5 Year 1999. POLRI as an investigator given authority by Law Number 5 of 1999 to assist KPPU in its efforts to enforce Business Competition Law. However, each institution remains obliged to carry out its duties and authority based on applicable laws and regulations by referring to the Standard Operating Procedure (SOP) that has been agreed upon so that there is no overlapping of authority between KPPU and POLRI.

This study suggests that there is a need for an SOP that explains the standards of implementation of each institution in handling cases of competition law crimes so that there is no overlapping authority between one institution and another.

12 Atmosudirjo, P. (1998). Hukum Administrasi Negara. Jakarta: Bhakti Indonesia at 76.

13 Indroarto. (2003). Usaha Memahami Undang-Undang tentang Peradillan Tata Usaha Negara. Jakarta: Pustaka Sinar Harapan at 117.

14 Arifin, Y.M, Kewenangan Ideal Lembaga Penegak Hukum Persaingan Usaha di Indonesia, available online at https://dspace.uii.ac.id/handle/123456789/13977 accessed in June 172019. 


\section{REFERENCES}

Atmosudirjo, P. (1998). Hukum Administrasi Negara. Jakarta: Bhakti Indonesia.

Chandra, A., and Widiyaatuti, Y.S.M. (2017). Peran Komisi Pengawas Persaingan Usaha (KPPU) Dalam Mendorong Iklim Persaingan Usaha Yang Sehat Di Sektor Perunggasan. Jurnal Justisi et Pax, Vol.33 (No.l), pp.l-1l, DOI: https://doi.org/ 10.24002/jep.v33il.1416.

Fadhilah, M. (2019). Penegakan Hukum Persaingan Usaha Tidak Sehat Oleh Komisi Pengawas Persaingan Usaha (KPPU) Dalam Kerangka Ekstrateritorial. Jurnal Wawasan Yuridika, Vol.3 (No.1), pp. 55-72, DOI: http://dx.doi.org/10.25072/jwy.v3il. 217

Indroarto. (2003). Usaha Memahami Undang-Undang tentang Peradillan Tata Usaha Negara. Jakarta: Pustaka Sinar Harapan.

Komisi Pengawas Persaingan Usaha (KPPU), Hukum Persaingan Usaha Antara Teks \& Konteks.

Komisi Pengawas Persaingan Usaha (KPPU), KPPU-POLRI: Pererat Kerjasama Dengan Pengesahan Prosedur Pelaksanaan MOU, Available online from: http://www.kppu.go.id/id/blog/201l/05/kppu-polri-pererat-kerjasama-denganpengesahan-prosedur-pelaksanaan-mou/ accessed in July, 2019.

Mantili, R., Kusmayanti, H., \& Afriana, A. (2016). The Problem of Law Enforcement in Business Competition in Estabilishing Legal Certainty. PADJADJARAN Jurnal Ilmu Hukum, Vol.3 (No.1), pp. 116-132, DOI: https://doi.org/10.22304/pjih.v3nl.a7.

Mulyadi, D., \& Rusydi, I. (2017). Efektifitas Peran Komisi Pengawas Persaingan Usaha (KPPU) Dalam Penanganan Kasus Persaingan Usaha Tidak Sehat, Jurnal Ilmiah Galuh Justisi, Vol.5 (No.1), pp.1-20, DOI: http://dx.doi.org/10.25157/jigj.v5il.235

Salim, H.S., \& Nurbani, E.S. (2014). Penerapan Teori Hukum Pada Penelitian Tesis Dan Disertasi. Jakarta: PT RajaGrafindo Persada.

Silalahi, U. (2018). Single Economic Entity: Kajian Hukum Persaingan Usaha Di Indonesia, Jurisdictie: Jurnal Hukum dan Syariah, Vol.9 (No.1), DOI: http://dx.doi.org/ 10.18860/j.v9il.4903.

Simbolon, A.P. (2008). Komisi Pengawas Persaingan Usaha Dalam Penegakan Hukum Persaingan Usaha. Jurnal Mimbar Hukum, Vol.20 (No.3), pp.459-471, DOI: https://doi.org/10.22146/jmh.16288.

Supriatna. (2016). Persekongkolan Bisnis Dalam Bentuk Perjanjian Kartel. Jurnal Hukum POSITUM. Vol.1 (No.1).

Suteki., \& Taufani, G. (2018). Metodologi Penelitian Hukum (Filsafat, Teori Dan Praktik). Depok: PT Raja Grafindo Persada.

Sapitri, B.E. (2015). Kewenangan Komisi Pengawas Persaingan Usaha (KPPU) Dalam Penanganan Perkara Persaingan Usaha (Studi Perbandingan Di Indonesia Dengan Negara-Negara Common Law System), Jurnal IUS Kajian Hukum dan Keadilan, Vo.3 (No.1), pp.139-159, DOI: http://dx.doi.org/10.12345/ius.v3i7.204 . 
213 | LENTERA HUKUM

Y.M, Arifin. Kewenangan Ideal Lembaga Penegak Hukum Persaingan Usaha di Indonesia, available online at https://dspace.uii.ac.id/handle/123456789/13977 accessed in June 172019. 
214 | The Enforcement of Business Competition Law by the Police: An Indonesian Experience

This page is intentionally left blank 